\title{
Factors associated with hepatitis $C$ in residents of Sao Paulo, Brazil
}

\author{
Norma Farias,, Umbeliana Barbosa de Oliveira, Débora Moraes Coelho, lára de Souza, Claudia Afonso Binelli \\ From 17th International Symposium on HIV and Emerging Infectious Diseases (ISHEID) \\ Marseille, France. 23-25 May 2012
}

\section{Introduction}

Hepatitis C represents a global public health problem. The aim of the present study was to describe the epidemiological profile and to assess exposure variables associated with hepatitis $\mathrm{C}$ in residents of Sao Paulo, from the database of viral hepatitis at the National Databank of Major Causes of Morbidity.

\section{Material and methods}

We analyzed 24,140 cases of hepatitis $C$ notified in residents of the State of Sao Paulo, among the 46,969 bank records of viral hepatitis between 2007 and 2010. Suspected cases of hepatitis $C$ have been confirmed by the presence of HCV RNA using reverse transcription-polymerase chain reaction (RT-PCR). The variables selected from the notifications files were sex, age, race, education, number of sexual partners, history of sexually transmitted diseases, HIV/AIDS, intravenous drugs use, inhaled or crack, injecting drugs, tattooing/piercing, acupuncture, blood/products transfusion, surgical, dental treatment, hemodialysis, transplantation and accidents with biological material. Factors associated with HCV infection were identified with univariate and multivariate Poisson regression and confidence intervals of $95 \%$.

\section{Results}

The detection rate of hepatitis $C$ was about $15 / 100000$ inhabitants. People aged 50 and over $(\mathrm{PR}=2,11 ; 95 \%$ CI:1,96-2,27), history of blood transfusion ( $\mathrm{PR}=1,41 ; 95 \%$ CI: 1,34-1,48), intravenous drugs use $(\mathrm{PR}=1,33 ; 95 \% \mathrm{CI}$ : $1,25-1,42)$, inhalable drugs use or crack $(\mathrm{PR}=1,27(1,20$ 1,35), HIV/AIDS ( $P R=1,20 ; 95 \%$ CI:1,13-1,28), surgical treatment in the past ( $\mathrm{PR}=1,16 ; 95 \% \mathrm{CI}: 1,11-1,21)$ were

* Correspondence: norma.o.farias@gmail.com

Epidemiology at Secretaria de Estado Da Saúde de São Paulo- Brazil, Sao Paulo, Brazil the main factors independently associated with infection by hepatitis $\mathrm{C}$ virus.

\section{Conclusions}

These findings reinforce the importance of preventing hepatitis $C$ in vulnerable populations such as drug users and the implementation of drugs misuse related harm reduction programs targeted these segments.

Published: 25 May 2012

doi:10.1186/1742-4690-9-S1-P53

Cite this article as: Farias et al:: Factors associated with hepatitis $C$ in

residents of Sao Paulo, Brazil. Retrovirology 2012 9(Suppl 1):P53.
Submit your next manuscript to BioMed Central and take full advantage of:

- Convenient online submission

- Thorough peer review

- No space constraints or color figure charges

- Immediate publication on acceptance

- Inclusion in PubMed, CAS, Scopus and Google Scholar

- Research which is freely available for redistribution
() Biomed Central 